\title{
Phenotypic Response of Two Garlic Varieties to Different Nitrogen Fertilization Grown under Irrigation in Sudan Savannah Ecological Zone of Nigeria
}

\author{
Magaji G. Usman, ${ }^{1}$ A. S. Fagam, ${ }^{1}$ Rilwanu U. Dayi, ${ }^{2}$ and Zaharaddeen Isah ${ }^{1}$ \\ ${ }^{1}$ Department of Crop Production, School of Agriculture and Agricultural Technology, \\ Abubakar Tafawa Balewa University (ATBU), PMB 0248, Bauchi, Nigeria \\ ${ }^{2}$ Department of Agricultural Technology, College of Agriculture, Hassan Usman Katsina Polytechnic, \\ Tafawa Balewa Way, PMB 2052, Katsina State, Nigeria
}

Correspondence should be addressed to Magaji G. Usman; magajiusman0@gmail.com

Received 29 November 2015; Revised 12 March 2016; Accepted 17 April 2016

Academic Editor: Iskender Tiryaki

Copyright (C) 2016 Magaji G. Usman et al. This is an open access article distributed under the Creative Commons Attribution License, which permits unrestricted use, distribution, and reproduction in any medium, provided the original work is properly cited.

A study was conducted under irrigation during dry season at the Katsina State Irrigation Site, Ajiwa. The aim of the experiment was to enhance the productivity of garlic through the choice of appropriate levels of nitrogenous fertilizer and suitable cultivar which maximizes yield. The experiment consisted of two varieties (ex-kofa and ex-sokoto) and four levels of nitrogen $(0,50,100$, and $150 \mathrm{kgN} / \mathrm{ha}$ ). They were arranged in a randomized complete block design in three replications. The variety ex-sokoto was found superior to ex-kofa with respect to plant height, number of leaves, leaf area, and days to maturity, number of bulbs, bulb diameter, bulb weight, and number of cloves per bulb, cloves weight per bulb, and fresh and cured bulb yield. Application of $50 \mathrm{kgN} / \mathrm{ha}$ significantly increased plant height $(\mathrm{cm})$, number of leaves per plant, leaf area, number of bulbs, and the total yield of the garlic. Significant effects of interaction between variety and nitrogen on leaf area and number of cloves per bulb of the garlic were observed. The combination of ex-sokoto variety and $50 \mathrm{kgN} / \mathrm{ha}$ was found to increase garlic yield. Maximum growth and yield could be realized using a combination of ex-sokoto variety and $50 \mathrm{kgN} / \mathrm{ha}$ at Ajiwa.

\section{Introduction}

Garlic (Allium sativum L.) belongs to the family Alliaceae. It is the second most widely used among cultivated alliums after onion (Allium cepa). The crop consists of an underground bulb and above the ground vegetative part which consists of the leaves and flowers. The rooting system is fibrous while the bulbs comprise small bulbils called cloves, which are the vegetative propagating materials of the crop [1]. Garlic is a cold weather perennial crop with high nutrient and water requirement [2]. The crop is grown under both rain-fed and irrigated conditions. It gives good result when grown on fertile well-drained and sand or silt-loam soils, with good moisture retaining properties. Garlic is mainly used as a spice, seasoning, and flavouring for foodstuff involving both green tops and bulbs due to its pungent flavour [3]. Garlic nitrogen requirement is $5 \% \mathrm{~N}, 4 \% \mathrm{~N}$, and $3 \% \mathrm{~N}$ at prebulbing, bulbing, and postbulbing stages, respectively [4], and it is considered deficient in nitrogen with $4 \% \mathrm{~N}, 3 \% \mathrm{~N}$, and $2 \% \mathrm{~N}$ at early season, midseason, and late season, respectively [4].

India is one of the world's largest producers of garlic with an average yield of about 5.23 tonnes per hectare [5]. Other growers are Spain, Egypt, Korean Republic, Argentina, Italy, China, and the United States. According to [6], production of garlic stood at about 10 million tonnes per annum which is only about $10 \%$ of the production of bulb onions. The world average yield of garlic is about $10 \mathrm{t} / \mathrm{h}$ a but can go up to $19 \mathrm{t} / \mathrm{ha}$. In Nigeria, the crop has been in cultivation for decades in northern states such as Kano, Sokoto, Borno, Bauchi, Jigawa, Katsina, and Zamfara [7]. The sativum variety has a bulb with many pure white or pink-blushed bulblets [8].

Plant growth characteristics can vary tremendously from one location to another, complicating variety selection [9]. Significant variations were observed for various garlic 
characteristics such as the relative growth rate, plant height, number of leaves, leaf area, and net assimilate rate [10-13] due to grown cultivars. Recently, [14] reported variations in plant vigour among six garlic genotypes tested with Egaseed 1 and Sid 40 recorded the highest plant vigour compared to the other varieties. Earlier reports [3] showed that there was significant difference in plant height among the tested varieties. Variety Tsedey 92 recorded the highest plant height compared to the local variety Rie at Tegahne irrigation site, Golgol Naele, and Atsbi Womberta Wereda. It was reported in [15] that there was significant difference among 17 cultivars of garlic in plant height in 1995 rainy and 1996 dry seasons (under irrigation) at Debre Zeit.

Chemical fertilizers have become widely used in vegetable production in tropical areas, particularly, where they are readily available. It is well known that the use of fertilizer helps in production and is somewhat a quick method for achieving maximum yield [16]. Nitrogen is generally found deficient in most of the African soils particularly in the areas where farmers practice intensive cultivation and grow high yielding varieties [17]. Availability of nitrogen is of prime importance for growing plants as it is an integral part of chlorophyll molecules, which are responsible for photosynthesis [18]. A high rate of nitrogen induces growth, forms high amount of proteins, and, by competence, reduces anthocyanin synthesis because a high amount of amino acids is destined to form proteins [19]. Nitrogen is among the most important nutrient elements in garlic and other crops and actively acts in numerous metabolic processes. Nitrogen supply was reported [20] to affect growth and assimilation rates in plant mainly by altering the size of the photosynthetic apparatus (leaf area) and it may also affect leaf efficiency. Nitrogen fertilizer increased the rate of leaf appearance and the rate of leaf extension particularly for the first leaf, following effects on tissue nitrogen. Bulb growth also responded significantly to applied nitrogen [20]. Increasing nitrogen rates to $100 \mathrm{kgN} /$ ha resulted in longer leaves and greater number of leaves per plant [21]. In another trial [2], the growth and yield parameters increased with increasing nitrogen rates up to $150 \mathrm{kgN} / \mathrm{ha}$. However, higher rates of nitrogen beyond $150 \mathrm{~kg}$ decreased growth and yield. $200 \mathrm{kgN} / \mathrm{ha}$ significantly increases the yield parameters like neck thickness, bulb diameter, number of cloves per bulb, and fresh weight of 20 cloves [22]. However, at Samaru in Nigeria [23] nitrogen application increased almost all growth and yield parameters of garlic significantly and the maximum yield of $15 \mathrm{t} /$ ha was recorded with $90 \mathrm{kgN} / \mathrm{ha}$. Furthermore [24] recorded significant increase in bulb yield with the application of $75 \mathrm{kgN} /$ ha while clove weight increased only at $150 \mathrm{kgN} / \mathrm{ha}$ beyond which there was a significant reduction.

The wide gap between present low yield and the potential yield of garlic in Nigeria is an indication of several constraints that are limiting garlic production. Some of these limiting factors are environmental, While other factors are due to agronomic or cultural practices. Some of the major constraints include inadequate fertilizer, weeds, chemicals, storage, and transportation facilities. However, the per-hectare yield of garlic can be increased by adopting proper package of practices like timely planting, proper spacing, and judicious application of irrigation water, and besides these balance application of nitrogen plays a vital role in the development of garlic [21]. There is dearth of information on garlic production in Nigeria, except for some works done at Samaru on spacing, fertilizer, and irrigation requirements [24]. Generally, it is in view of this background that this study was undertaken with the aim of exploring opportunities to improve the productivity of garlic through the choice of appropriate levels of nitrogenous fertilizer and suitable cultivar which maximizes yield. The objectives were to determine the influence of nitrogenous fertilizer on the performance of two garlic varieties and their interactions. The hypothesis for this work was as follows: $\mathrm{H}_{0}$ there is no significant variation between the two garlic varieties with respect to their growth and yield performance and different nitrogen fertilization does not affect the growth and yield of garlic.

\section{Materials and Methods}

2.1. Site and Location. Field experiment was conducted under irrigation during 2010/2011 dry season at the Katsina State Irrigation Site, Ajiwa. The site is approximately located at $13^{\circ} 01^{\prime} \mathrm{N}$ and $7^{\circ} 41^{\prime} \mathrm{E}$ and $619 \mathrm{~m}$ above sea level in the Sudan savannah ecological zone of Nigeria [26]. The soil of the experimental site was loamy soil. A detail of the physiochemical analysis of the soil was presented in Table 4, while meteorological data was presented in Table 5.

2.2. Treatments and Experimental Design. The treatments consisted of factorial combination of two garlic varieties (exkofa and ex-sokoto) and four nitrogen rates (0, 50, 100, and $150 \mathrm{kgN} / \mathrm{ha}$ ). These were arranged in a randomized complete block design and replicated three times. The total area for the experiment was $16 \mathrm{~m} \times 6.5 \mathrm{~m}$. The field was further made into three replicates with $1.0 \mathrm{~m}$ spacing between the replicates. Each replicate comprises 8 plots (each representing a treatment combination) with $0.5 \mathrm{~m}$ spacing between the plots. The experimental field was cleared, ploughed, and harrowed to pulverize the soil before making a plot of $1.5 \mathrm{~m}$ $\times 1.5 \mathrm{~m}$ as gross size in sunken appearance. The gross plot size was $2.25 \mathrm{~m}^{2}$ and the net plot size was $1 \mathrm{~m}^{2}$. The net plot was "the central area where observations were taken." This is to avoid bias due to interference between plots. The plots were bounded by low bounds in order to retain the irrigation water. The uniforms inter- and intrarow spacing of $10 \mathrm{~cm}$ were used. Each gross size plot consists of 15 rows with 15 holes per row and a total of 225 plants per plot and 100 per net plot (10 rows with 10 holes per row). The total plant population was 5.400 plants during the experimental period. The crop received an application of nitrogen fertilizer as urea (46\%) according to the treatments in two equal split doses. A basal dose of half the nitrogen rate was applied and incorporated at sowing. The second dose of the nitrogen was applied at four weeks after sowing (4WAS). The fertilizer was incorporated manually using hand hoe.

2.3. Experimental Material. Local variety of garlic ex-kofa is popularly grown around Kofa village in Kano State. 
The matured bulb is globular in shape with white "skin" or outer covering. The bulbs are medium in size and sealed up at the tip. The ex-sokoto is also a local variety commonly grown in Sokoto State. The matured bulb is not completely round. The bulb has protruded cloves. This variety is also called Hyena Hoof. These varieties were selected based on their high bulb yield and pungent flavour.

2.4. Plant Husbandry. The land preparation was carried out in the last week of December, 2010. Planting was carried out on December 30 in the 2010/2011 dry season. A day before planting, bulbs were separated into individual cloves with only the large and healthy ones selected and soaked in water overnight in order to remove the scale leaves covering the clove which enhanced rapid sprouting. The basins were preirrigated a day prior to planting. Planting was done manually on the prepared plots with one clove planted per stand. The cloves were placed into the soil $2-3 \mathrm{~cm}$ deep with the growing point upward and covered lightly with soil for consolidation. The experimental field was irrigated by surface flooding method, every three days during the early stages of growth and later every four days. Irrigation was stopped two weeks before harvest to allow for uniform maturity. Weeding was done manually using both handpicking and hoes weeding. The weeding was carried out at 4,6 , and 8 weeks after sowing. There was no observable incidence of either pest or disease attack on the crop throughout the growing period.

2.5. Morphophysiological Parameters. Characters assessed include plant height, number of leaves, leaf area, and number of days to $50 \%$ maturity, matured bulb diameter, individual bulb weight, and number of cloves per bulb, cloves weight per bulb, fresh bulb yield, and cured bulb yield (Table 1).

2.6. Data Analysis. Results were analysed using SAS version 9.3 computer software for all characters assessed [27]. Least significance difference (LSD) was used to separate the significantly different means and their interactions. The mean values of the dependent and independent variables were also subjected to correlation coefficients. Association of the various characters with yield per plant and among themselves was worked out at phenotypic level according to the method given in [28].

\section{Results}

3.1. Garlic Varietal Response on Growth Characters. The varieties differed significantly $(p<0.05)$ at most stages of growth in affecting the plant height, number of leaves, leaf area (Figures 1-3), and days to $50 \%$ maturity (Figure 4(a)) of garlic during the course of the study. The variety ex-sokoto consistently produced taller plants and grew more leaves with greater leaf area compared to ex-kofa. The growth of these parameters increases from 4WAS to 8WAS after which it declines. However, ex-kofa took the highest number of days to $50 \%$ maturity of the garlic plants compared to the ex-sokoto variety (Figure $4(a)$ ).

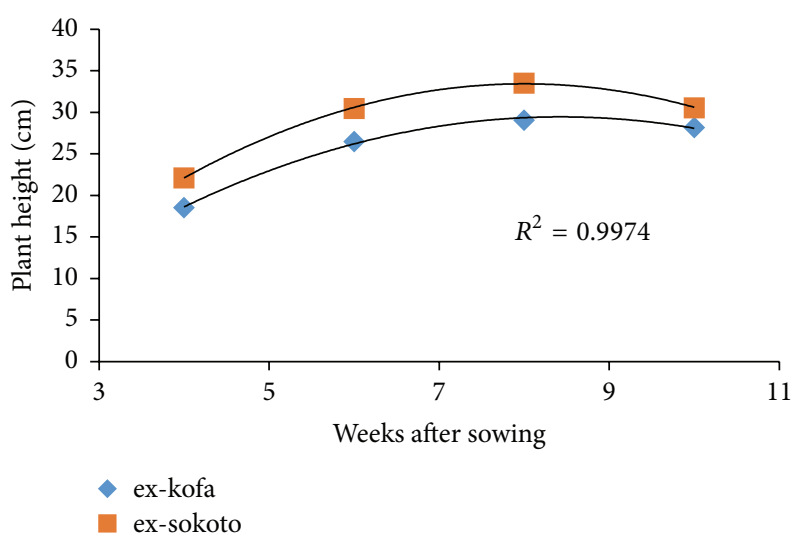

FIGURE 1: Significant $(p<0.05)$ growth trend of garlic varieties at 4 , 6,8 , and 10 weeks after sowing on plant height. $R^{2}$ is the goodness of fit.

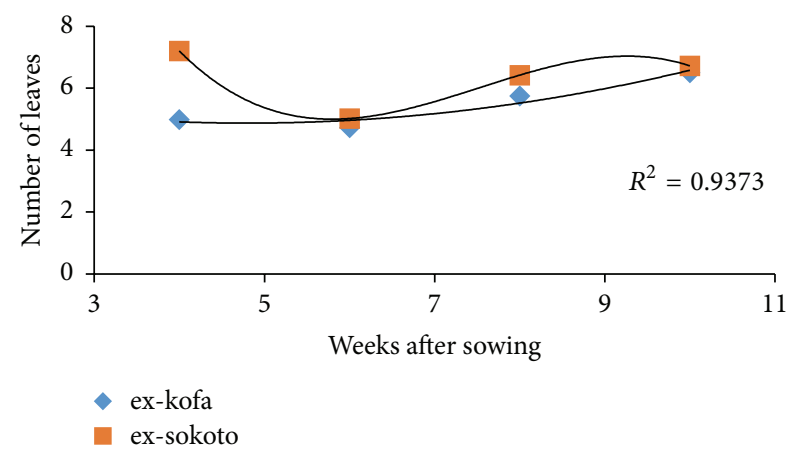

FIGURE 2: Significant $(p<0.05)$ growth trend of garlic varieties at $4,6,8$, and 10 weeks after sowing on number of leaves. $R^{2}$ is the goodness of fit.

Effect of interaction between variety and nitrogen rates on the garlic leaf area at 6WAS differed significantly $(p<0.05)$ during the study as shown in Figure 5. Increase in nitrogen rates from 0 to $50 \mathrm{kgN} /$ ha significantly increased leaf area in ex-sokoto with no significant influence on ex-kofa. The significant difference in the variety and nitrogen rates was found in the combination of ex-sokoto and $50 \mathrm{kgN} / \mathrm{ha}$.

3.2. Effect of Nitrogen on the Growth Performance of Garlic during the Period of the Experiment. Plant height, number of leaves, and leaf area differed significantly with different nitrogen rates (Figures $6-8$ ). $50 \mathrm{kgN} /$ ha produced similar plant height and grew more leaves compared with the control $0 \mathrm{kgN} / \mathrm{ha}$ which was significantly higher than 100 and $150 \mathrm{kgN} / \mathrm{h}$. The growth increases from 4WAS to 8WAS after which it declines. Similarly, nitrogen response differed significantly $(p<0.05)$ in days to $50 \%$ maturity (Figure $4(\mathrm{~b})$ ).

With regard to the effect of nitrogen rates on the number of bulbs, fresh bulb and cured bulb yield responded significantly (Table 2). $50 \mathrm{kgN} / \mathrm{ha}$ recorded the maximum number of bulbs and high bulb yield, while $150 \mathrm{kgN} / \mathrm{ha}$ recorded the lowest. 
TABLE 1: Description of characters assessed during the study.

\begin{tabular}{ll}
\hline Parameters assessed & Description \\
\hline Plant height & Measured from the ground level to the tip of the tallest leaf with the aid of meter rule \\
Number of leaves & Recorded as the mean number of fully opened leaves from the 10 sampled plants \\
Leaf area & Leaf area was measured and calculated using leaf parameter method as described in [25] \\
Number of days to 50\% maturity & Number of plants with dried leaves in each plot was counted at maturity stage \\
Matured bulb diameter & Measured using vernier calliper from 10 air-cured bulbs with the mean expressed in centimeter \\
Individual bulb weight & Ten air-cured bulbs sampled per plot were weighed on Mettler balance \\
Number of cloves per bulb & Cloves were separated from each of the 10 bulbs sampled per plot and counted \\
Cloves weight per bulb & The weights of cloves separated per each of the 10 sampled bulbs were measured using Mettler \\
Fresh bulb yield & balance \\
Cured bulb yield & Total weight of fresh bulb harvested from each net plot was recorded \\
\hline
\end{tabular}

TABLE 2: Effect of variety and nitrogen rates on the yield and yield components of garlic during the 2010/2011 dry season at Ajiwa.

\begin{tabular}{|c|c|c|c|c|c|c|c|}
\hline Treatment & $\begin{array}{l}\text { Matured bulb } \\
\text { diameter } \\
(\mathrm{cm})\end{array}$ & $\begin{array}{c}\text { Individual } \\
\text { bulb weight } \\
(\mathrm{g})\end{array}$ & $\begin{array}{c}\text { Number of } \\
\text { cloves per } \\
\text { bulb }\end{array}$ & $\begin{array}{l}\text { Cloves weight } \\
\text { per bulb (g) }\end{array}$ & $\begin{array}{l}\text { Number of } \\
\text { bulbs }\end{array}$ & $\begin{array}{c}\text { Fresh bulb } \\
\text { yield (kg/ha) }\end{array}$ & $\begin{array}{l}\text { Cured bulb } \\
\text { yield (kg/ha) }\end{array}$ \\
\hline \multicolumn{8}{|l|}{ Variety } \\
\hline ex-kofa & $0.53^{\mathrm{b}}$ & $1.41^{\mathrm{b}}$ & $6.55^{\mathrm{b}}$ & $1.25^{\mathrm{b}}$ & $20.42^{\mathrm{b}}$ & $422.50^{\mathrm{b}}$ & $224.17^{\mathrm{b}}$ \\
\hline ex-sokoto & $0.71^{\mathrm{a}}$ & $1.77^{\mathrm{a}}$ & $7.33^{\mathrm{a}}$ & $1.64^{\mathrm{a}}$ & $29.75^{\mathrm{a}}$ & $625.00^{\mathrm{a}}$ & $429.17^{\mathrm{a}}$ \\
\hline Mean & 0.62 & 1.59 & 6.94 & 1.45 & 25.09 & 523.75 & 326.67 \\
\hline $\mathrm{STD} \pm$ & 0.13 & 0.25 & 0.55 & 0.28 & 6.60 & 143.19 & 144.96 \\
\hline $\operatorname{LSD}(p<0.05)$ & 0.12 & 0.32 & 0.70 & 0.32 & 5.26 & 185.81 & 126.49 \\
\hline \multicolumn{8}{|c|}{ Nitrogen rates $(\mathrm{kg} / \mathrm{ha})$} \\
\hline 0 & 0.62 & 1.62 & 6.70 & 1.48 & $28.17^{\mathrm{a}}$ & $611.67^{\mathrm{a}}$ & $361.67^{\mathrm{a}}$ \\
\hline 50 & 0.73 & 1.88 & 7.33 & 1.70 & $30.17^{\mathrm{a}}$ & $661.67^{\mathrm{a}}$ & $410.00^{\mathrm{a}}$ \\
\hline 100 & 0.57 & 1.50 & 7.03 & 1.40 & $22.83^{\mathrm{a}}$ & $506.67^{\mathrm{a}}$ & $298.33^{\mathrm{a}}$ \\
\hline 150 & 0.55 & 1.35 & 6.70 & 1.20 & $19.17^{\mathrm{b}}$ & $315.00^{\mathrm{b}}$ & $236.67^{b}$ \\
\hline Mean & 0.62 & 1.59 & 6.94 & 1.45 & 25.09 & 523.75 & 326.67 \\
\hline $\mathrm{STD} \pm$ & 0.07 & 0.19 & 0.26 & 0.18 & 4.34 & 132.87 & 65.33 \\
\hline $\operatorname{LSD}(p<0.05)$ & - & - & - & - & 7.44 & 262.77 & 140.98 \\
\hline
\end{tabular}

Means with the same letter are not significantly different. LSD: least significant difference. STD: standard deviation.

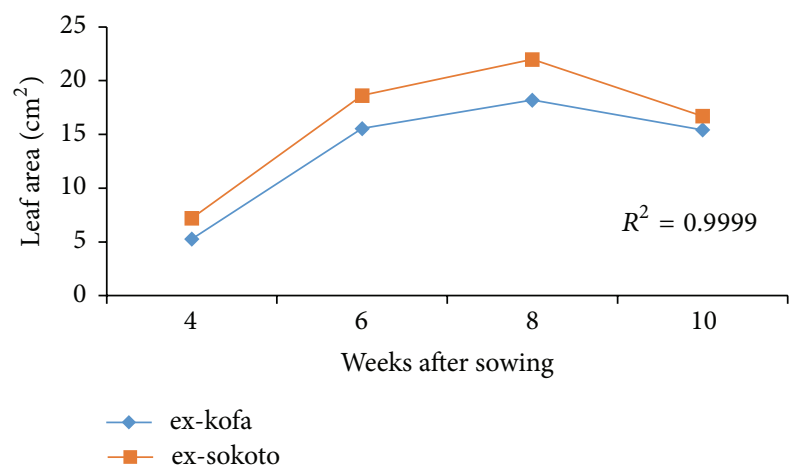

FIGURE 3: Significant $(p<0.05)$ growth trend of garlic varieties at 4 , 6,8 , and 10 weeks after sowing on leaf area.

3.3. Yield and Yield Components Response to Different Nitrogen Rates and Garlic Varieties. The result in Table 2 shows the effect of variety and nitrogen rates on the matured bulb diameter, individual bulb weight, number and weight of cloves per bulb, number of bulbs, and fresh and cured bulb weights. The effect of variety was highly significant $(p<0.05)$ in affecting all the yield and yield components of garlic during the period of the experiment. The variety ex-sokoto appeared to be superior to ex-kofa throughout the experiment (Table 2).

The significant effect of nitrogen rates showed that $50 \mathrm{kgN} /$ ha gave significantly higher number of bulbs and fresh and cured bulb weights than $150 \mathrm{kgN} / \mathrm{ha}$ which was similar with the control and $100 \mathrm{kgN} / \mathrm{ha}$. Nitrogen application increases bulb yield initially at an increasing rate and then increases at a decreasing rate and then later at higher dose significantly decreases at a decreasing rate. On the contrary, matured bulb diameter and individual bulb weight and number and weight of cloves per bulb showed no significant effect (Table 2). 


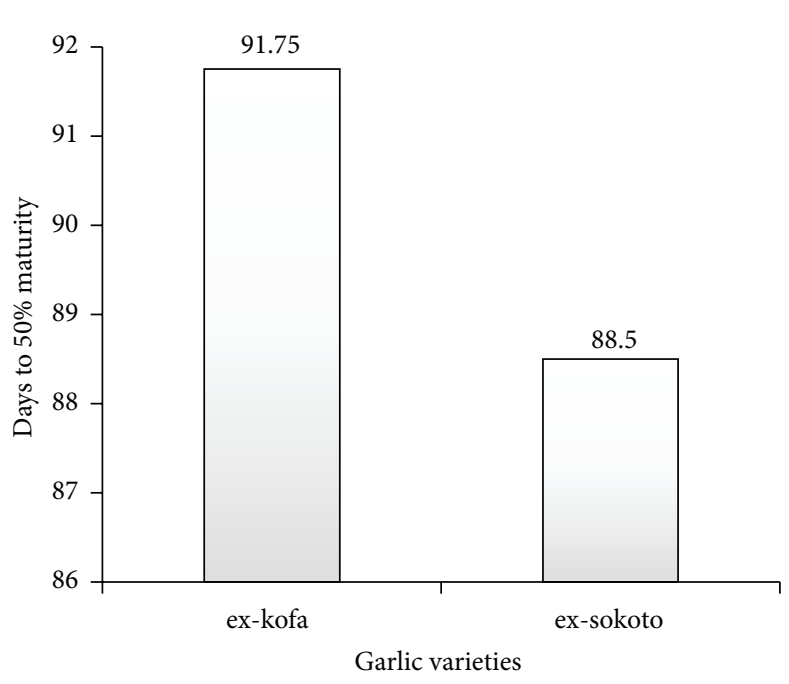

(a)

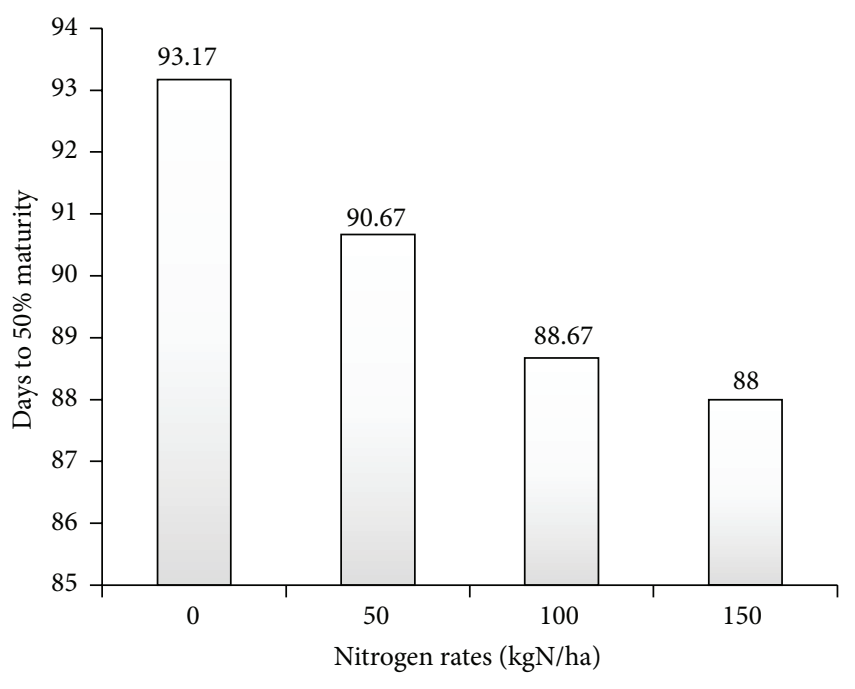

(b)

FIGURE 4: Significant differences $(p<0.05$ ) between (a) variety, least significant difference (LSD) 3.23, and (b) different nitrogen rates, LSD 4.57 , in the days to $50 \%$ maturity of garlic.

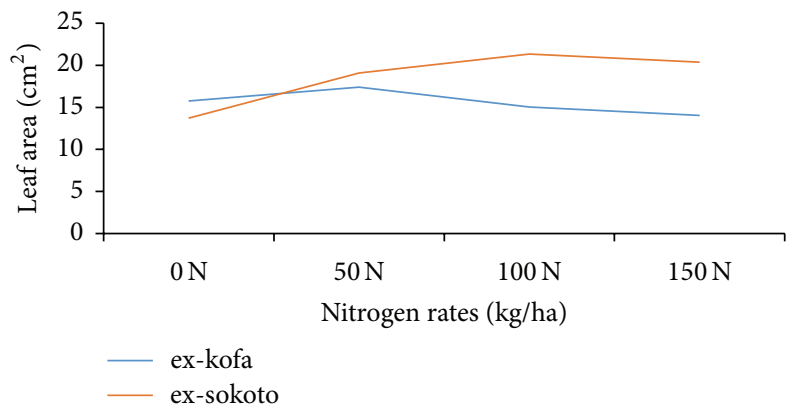

FIGURE 5: Interaction effect of variety and nitrogen rates on the leaf area at 6 WAS $(\mathrm{LSD}=4.54)$.

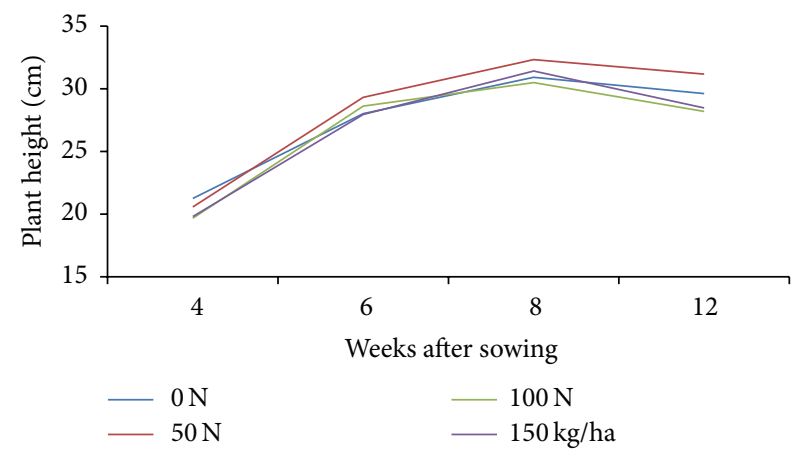

Figure 6: Significant $(p<0.05)$ growth trend of garlic response to different nitrogen rates at $4,6,8$, and 10 weeks after sowing on plant height during the period of the experiment.

The effect of interaction between variety and nitrogen rates was found significant on the number of cloves per bulb of garlic during the period of the experiment (Figure 9). This was apparent from the difference in the main effects (variety and nitrogen). The result further depicts that $50 \mathrm{kgN} / \mathrm{ha}$

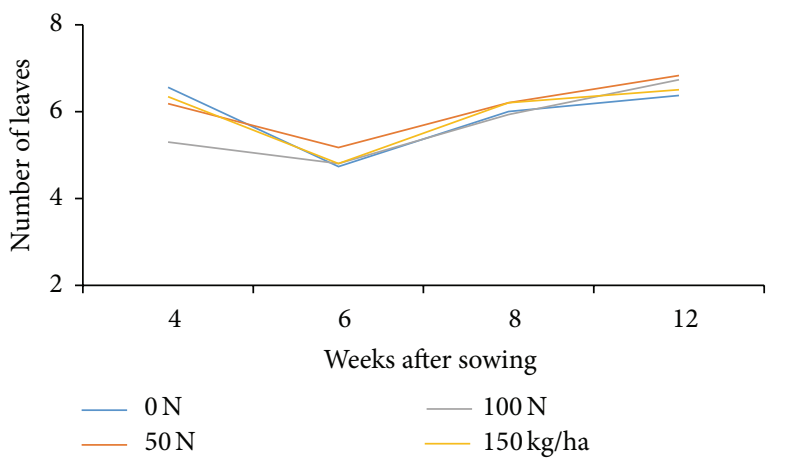

FIGURE 7: Number of leaves' response to different nitrogen rates throughout the period of the experiment.

significantly gave the highest number of cloves per bulb compared to the control $0 \mathrm{kgN} / \mathrm{ha}$ with ex-sokoto variety beyond which there was no significant reduction. The ex-kofa variety produced similar number of cloves per bulb of garlic with all the nitrogen rates.

3.4. Correlation between Studied Characters. To study the relationship between the yields and yield components correlation coefficient analysis was performed [27]. This helps to establish a better understanding of the relationship among the yield and yield related characters such as plant height, number of leaves, leaf area, number of bulbs, and cloves weight. Significant $(p<0.05)$ and very strong-positive phenotypic relationships were observed among individual bulb weight, cloves weight per bulb, number of bulbs, and fresh bulb and cured bulb yield characters (Table 3 ). Besides, matured bulb diameter and individual bulb weight were found to have a significant strong-positive association with plant height. 
TABLE 3: Coefficient of phenotypic correlations among the investigated garlic characters as response to different nitrogen rates.

\begin{tabular}{|c|c|c|c|c|c|c|c|c|c|c|c|c|c|}
\hline & PH8 & PH10 & NLs8 & NLs10 & LA8 & LA10 & MBD & IBW & $\mathrm{NCB}$ & CWB & NB & FBY & CBY \\
\hline PH8 & 1 & & & & & & & & & & & & \\
\hline PH10 & 0.810 & 1 & & & & & & & & & & & \\
\hline NLs8 & 0.881 & 0.469 & 1 & & & & & & & & & & \\
\hline NLs10 & 0.420 & 0.346 & 0.165 & 1 & & & & & & & & & \\
\hline LA8 & 0.897 & 0.635 & 0.765 & 0.750 & 1 & & & & & & & & \\
\hline LA10 & 0.871 & 0.866 & 0.562 & 0.738 & 0.906 & 1 & & & & & & & \\
\hline MBD & 0.761 & $0.978^{*}$ & 0.368 & 0.509 & 0.669 & 0.914 & 1 & & & & & & \\
\hline IBW & 0.624 & $0.936^{*}$ & 0.184 & 0.511 & 0.554 & 0.854 & $0.982^{*}$ & 1 & & & & & \\
\hline NCB & 0.548 & 0.613 & 0.188 & 0.946 & 0.770 & 0.876 & 0.754 & 0.763 & 1 & & & & \\
\hline CWB & 0.524 & 0.883 & 0.060 & 0.531 & 0.485 & 0.808 & $0.949^{*}$ & $0.991^{*}$ & 0.776 & 1 & & & \\
\hline NB & 0.436 & 0.880 & -0.004 & 0.240 & 0.271 & 0.648 & 0.896 & $0.946^{*}$ & 0.540 & $0.950^{* *}$ & 1 & & \\
\hline FBY & 0.268 & 0.768 & -0.203 & 0.312 & 0.179 & 0.577 & 0.826 & 0.914 & 0.583 & $0.947^{*}$ & $0.973^{* *}$ & 1 & \\
\hline CBY & 0.474 & 0.892 & 0.021 & 0.346 & 0.351 & 0.713 & 0.926 & $0.973^{*}$ & 0.629 & $0.979^{*}$ & $0.994^{* *}$ & $0.975^{* *}$ & 1 \\
\hline
\end{tabular}

${ }^{*}$ Significant at $5 \% .{ }^{* *}$ Highly significant at $1 \%$. PH8: plant height at 8WAS, PH10: plant height at 10WAS, NLs8: number of leaves at 8WAS, NLs10: number of leaves at 10WAS, LA8: leaf area at 8WAS, LA10: leaf area at 10WAS, MBD: matured bulb diameter, IBW: individual bulb weight, NCB: number of cloves per bulb, CWB: cloves weight per bulb, NB: number of bulbs, FBY: fresh bulb yield, and CBY: cured bulb yield.

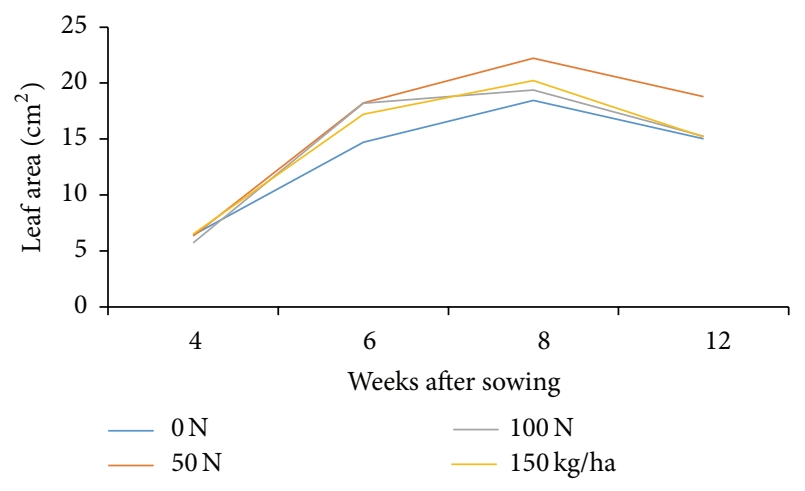

FIGURE 8: Significant $(p<0.05)$ growth trend of garlic response to different nitrogen rates at $4,6,8$, and 10 weeks after sowing on leaf area during the period of the experiment.

\section{Discussion}

4.1. Garlic Varietal Response to Growth Characters. Leaf is a food manufacturing factory for plants. Leaf area is directly related to photosynthesis as it provides more area for photosynthetic activity which consequently affects the yield. The photosynthetic material synthesized in the leaves primarily flows down to the root zone for bulb formation. Hence, plant height, the number of leaves, and leaf area are some of the most important measures of the plant vigour in garlic. Leaf number is directly related to variety characteristics [3]. The garlic varieties tested were the available varieties cultivated in the neighbouring areas of Ajiwa, Katsina State. They are mostly preferred by the consumer. The variety ex-sokoto appeared to be more vigorous in terms of plant height, number of leaves, and leaf area compared to the ex-kofa, thereby producing taller plants, and it grew higher number of leaves and wider leaves (leaf lamina). This work is in accordance with the work [29] that reported significant leaf number difference among garlic accessions and with the

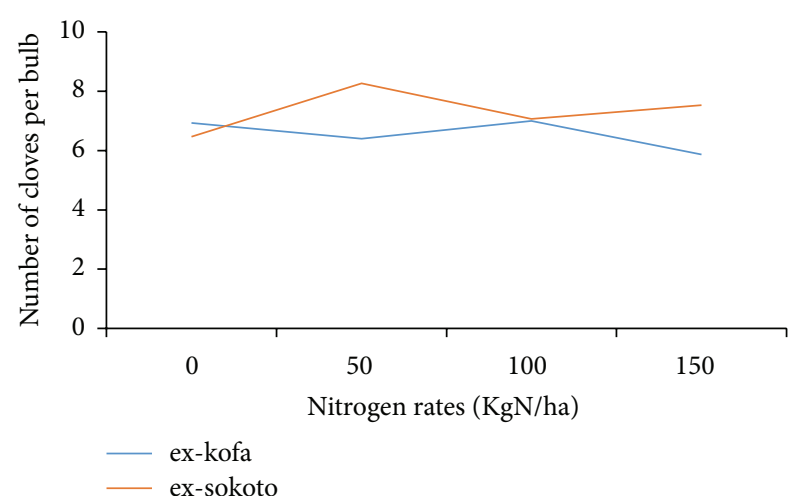

FIGURE 9: Interaction effect of variety and nitrogen rates on the number of cloves per bulb (LSD = 1.68).

findings of [30] that reported significant difference in leaf width and length in Iranian garlic. In addition, the variety ex-kofa took more days to mature compared to the ex-sokoto variety indicating that ex-sokoto variety matures earlier than the ex-kofa variety. This is in harmony with the work [31] in which it was observed that Xian variety was earlier to mature and was harvested 18 days before the other tested varieties.

4.2. Response of Nitrogen to the Growth Performance of Garlic during the Period of the Experiment. Plant height was apparently increased with increase in nitrogen up to $50 \mathrm{kgN} / \mathrm{ha}$ beyond which there was significant reduction at the later stage of growth (12WAS). The increase in plant height due to increase in nitrogen application indicates the positive role of nitrogen in plant growth and that the soil was deficient in nitrogen for garlic requirement. This agrees with the works of [16] that reported significant increase in plant height with the application of nitrogen fertilizer. Particularly at the early stage of growth, the maximum number of leaves per plant was recorded with $50 \mathrm{kgN} / \mathrm{ha}$ which was significantly 
TABLE 4: Physical and chemical properties of soil of the experimental site during 2010/2011.

\begin{tabular}{lcc}
\hline \multirow{2}{*}{ Soil characteristics } & \multicolumn{2}{c}{ Soil depth } \\
& $0-15 \mathrm{~cm}$ & $15-30 \mathrm{~cm}$ \\
\hline Chemical properties & \\
$\mathrm{pHw}(1: 1)$ & 6.22 & 6.09 \\
$\mathrm{pHc}(1: 2)$ & 5.47 & 5.32 \\
Organic carbon (\%) & 0.74 & 0.36 \\
Total nitrogen (\%) & 0.97 & 0.58 \\
Available phosphorus (\%) & 7.36 & 6.44 \\
\hline Exchangeable bases (meq/100g) & & \\
Ca & 2.53 & 2.62 \\
Mg & 0.73 & 0.55 \\
K & 0.21 & 0.19 \\
Na & 0.28 & 0.24 \\
CEC & 7.38 & 6.81 \\
Zn & 0.36 & 0.39 \\
Cu & 0.19 & 0.30 \\
Fe & 7.13 & 8.47 \\
Mn & 13.09 & 15.26 \\
\hline Physical properties & & \\
Sand (\%) & 81.68 & 83.68 \\
Silt (\%) & 8.56 & 7.76 \\
Clay (\%) & 9.76 & Loam \\
Textural class & Loam &
\end{tabular}

TABLE 5: Mean rainfall, maximum and minimum temperature, and relative humidity at monthly interval during the period of the experiment 2010/2011 dry season.

\begin{tabular}{lcccc}
\hline Month & Rainfall $(\mathrm{mm})$ & $\begin{array}{c}\text { Temperature } \\
\left({ }^{\circ} \mathrm{C}\right)\end{array}$ & $\begin{array}{c}\text { Relative humidity } \\
(\%)\end{array}$ \\
\hline 2010 & & & \\
Max. & Min. & \\
October & 92.58 & 31.50 & 20.75 & - \\
November & - & 32.75 & 21.50 & - \\
December & - & 30.25 & 17.75 & - \\
\hline 2011 & & & & - \\
January & - & 26.92 & 16.05 & - \\
February & - & 31.52 & 17.85 & 22.24 \\
March & - & 33.85 & 20.10 & 38.30 \\
\hline
\end{tabular}

Source: Weather Station, Katsina State Agricultural and Rural Development Authority, Katsina, Nigeria.

higher than the control. This depicts that the increase in number of leaves per plant as a result of an increase in nitrogen indicates the positive role of nitrogen in increasing the rates of leaf initiation and extension in early growth. This finding is in harmony with the study of [21] that reported that application of nitrogen significantly increased number of leaves per plant. Similarly, further increment of nitrogen dose above $50 \mathrm{kgN} / \mathrm{ha}$ has led to a reduction in the leaf area. This could be explained on the basis that nitrogen supply affects growth and assimilation rates in plant mainly by altering the size of the photosynthetic apparatus (leaf area) and it may also affect leaf efficiency [32]. This is in agreement with [33] that reported that nitrogen application increased almost all growth parameters of garlic significantly.

In essence, plants grown with $50 \mathrm{kgN} / \mathrm{ha}$ produced the maximum vegetative growth, which possibly enhanced the maximum photosynthetic activity and accumulation of dry matter in the plants. The decrease in these traits as a result of higher rates of nitrogen above $50 \mathrm{kgN} / \mathrm{ha}$ could be due to imbalance of nutrients for excess application of nitrogen. However, with respect to days to $50 \%$ maturity the control ( $0 \mathrm{kgN} / \mathrm{ha}$ ) had the highest number of days to $50 \%$ maturity compared to the other nitrogen rates and $150 \mathrm{kgN} / \mathrm{ha}$ recorded the lowest. This shows that the more the increase in nitrogen the fewer the number of days to $50 \%$ maturity and the earlier the maturity. Similar conclusion was reported [34]. This agrees with the statement of the fact that a high level of nitrogen induces growth and forms a high level of proteins [19].

4.3. Response of Different Nitrogen Rates and Garlic Varieties on Yield Related Characters. According to this investigation garlic variety varies with respect to bulb diameter, bulb weight, number of cloves, and cloves weight. In harmony with this study, in [35] high variation was observed with respect to bulb weight, bulb diameter, and yield in garlic. This might indicate that bulb weight should be considered in the selection for garlic yield improving programs. The variety ex-sokoto which has protruded cloves and is not completely round produced the highest number of bulbs and fresh and cured bulb yield compared to the ex-kofa variety that is globular in shape. This might be due to the fact that yield and quality vary with variety of garlic [35]. The difference between the tested varieties on bulb diameter, number of cloves, and cloves weight might be due to the fact that garlic genotypes by environmental conditions had a high contribution to clove number and are controlled by the interaction effect of a number of genes. This investigation agrees with [12] that reported that among the tested varieties Clone 24 recorded the highest total number of cloves. It further reported the significant variation among the garlic varieties tested in bulb diameter, bulb weight, and cloves weight.

Availability of nitrogen is of prime importance for growing plants as it is a major and indispensable source of protein and nucleic acid molecules. It is also an integral part of chlorophyll molecules, which are responsible for photosynthesis. An adequate supply of nitrogen is associated with vigorous vegetative growth and more efficient use of available inputs finally leading to higher productivity. Production of maximum bulb yields by the application of nitrogen at $50 \mathrm{kgN} / \mathrm{ha}$ could be due to production of taller plants with higher number of leaves leading to increased formation of vegetative structure for nutrient absorption and photosynthesis and increased production of assimilates to fill the sink which result in increased bulb size and weight. The decrease in bulb yield at higher rates might be due to imbalance of nutrients for excess application of nitrogen. This investigation is in agreement with the findings of $[11,30]$ that 
observed significant increase in yield and yield components due to nitrogen application. The combination of ex-sokoto variety with nitrogen rate at $50 \mathrm{kgN} / \mathrm{ha}$ gave good vegetative growth and yield as when combined with the higher doses of 100 and $150 \mathrm{kgN} / \mathrm{ha}$ during the experimental period at the experimental site.

4.4. Correlation between Characters. Garlic bulb yield, as in other crops, is a quantitative character that is influenced by a number of yield contributing characters [36]. Association analysis measures the mutual relationship between various characters and it determines the component characters which could serve as selection criteria in crop improvement program. The selection of desirable genotypes is usually based on yield and yield components. From this analysis, it shows that taller plants have better bulb diameter that leads to a better bulb weight. The higher the bulb weight the better the clove weight and size, hence increasing the yield of garlic. In addition, number of bulbs has strong association with bulb yield.

\section{Conclusion}

Fertilizers vary in type and composition and since the range of soil types on which they can be used is also wide, firm recommendations for their application to specific crops can only be made if the local soil and climatic conditions are known. Based on the results obtained in this study, it could be suggested that the use of ex-sokoto in combination with $50 \mathrm{kgN} / \mathrm{ha}$ results in better garlic performance at Ajiwa. Furthermore, for the improvement of garlic production through selection matured bulb diameter, individual bulb weight, number of bulbs, and cloves weight per bulb could be suggested as revealed from this investigation.

However, the parameters discussed above are function of environmental variability, so estimates may differ in other environments but at Ajiwa and areas with similar soil and climate conditions this could be useful. Further researches could be carried out at various agroclimate and soil type to identify suitable varieties for maximum productivity.

\section{Competing Interests}

The authors declare that they have no competing interests.

\section{Acknowledgments}

The authors sincerely acknowledged Saleh Salleh who helped run the analysis.

\section{References}

[1] J. W. Purseglove, Tropical Crops Monocotyledons, Longman, London, UK, 1972.

[2] "Report on horticultural crops research programme," in Proceedings of the 1996 Cropping Scheme Meeting, Institute for Agricultural Research Ahmadu Bello University, Zaria, Nigeria, 1996.
[3] T. G. Tadese, Participatory varietal evaluation and farmers-based seed production. A sustainable approach to garlic seed delivery in Atsbi Womberta Woreda, Eastern Tigray [M.S. thesis], Department of Crop and Horticultural Science, Mekelle University, Mek'ele, Ethiopia, 2009.

[4] K. Tyler, D. May, J. Guerard, D. Ririe, and J. Hatakeda, "Diagnosing nutrient needs of garlic," California Agriculture, vol. 42, no. 2, pp. 28-29, 1988.

[5] National Horticultural Research and Development Foundation (NHRDF), 2008, http://nhrdf.com/.

[6] FAO-Food and Agricultural Organization. Rome, The Origin and Distribution of Garlic, USDA Agricultural Research Unit, Washington, DC, USA, 2001.

[7] B. B. D. Inuwa, "A study of issues arising from the production of garlic (Allium sativum L.) in Nigeria," in Proceedings of the Training Workshop on Improving and Accelerated Garlic Production for Local and Export Needs in Nigeria at Food Crops Production Technology Transfer Station (FDA), p. 16, Dan Hassan, Kano, Nigeria, 2001.

[8] Gvodenovic-Varga and M. Vasic, "Response of Spring Garlic Ecotypes to environmental Growth conditions," Natura Montenegrina, Podgorica, vol. 8, no. 2, pp. 73-81, 2008.

[9] B. Roger, C. Jay, R. Becker et al., Growing Garlic in Minnesota, University of Minnesota Extension, 2008.

[10] A. A. Midan, M. M. El-Sayed, R. M. Khalil, and M. A. Fathalla, "Growth and assimilation performance in garlic in relation to grown cultivar and nitrogen fertilization," Emirates Journal of Food and Agriculture, vol. 4, no. 1, pp. 27-51, 1992.

[11] J. L. Brewester, Onions and Other Vegetable Alliums, Crop Production Science in Horticulture, Horticulture Research International, Wellesbourne, UK, 2008.

[12] A. Z. Osman, M. N. M. Hassan, and A. A. M. El-Hamied, "Effect of NPK fertilizer application dates on growth, yield and quality of two garlic cultivars," Minia Journal of Agricultural Research Development, vol. 13, no. 2, pp. 577-596, 1991.

[13] S. H. Aly, Growth and yield of some garlic ecotype as affected by different cultural practices under assiut conditions [Ph.D. thesis], Faculty of Agriculture Assiut University, 2010.

[14] S.-N. H. Gadel-Hak, Y. M. M. Moustafa, G. F. Abdel-Naem, and I. A. Abdel-Wahab, "Studying different quantitative and qualitative traits of some white- and colored-bulb garlic genotypes grown under a drip irrigation system," Australian Journal of Basic and Applied Sciences, vol. 5, no. 6, pp. 1415-1427, 2011.

[15] S. Brahman and M. N. Yousuf, Effect of Nitrogen and Potassium on the Growth and Yield of Garlic, Research Report for 2008, Spice Research Centre, Bari, Bangladesh, 2008.

[16] I. S. Naruka and R. S. Dhaka, "Effect of row spacing and nitrogen fertilization on growth, yield and composition of bulb in garlic (Allium sativum L.) cultivars," Journal of Spices and Aromatic Crops, vol. 10, no. 2, pp. 111-117, 2001.

[17] H. B. Singh, The Role of Manures and Fertilizers in Crop Production, Developing Agric-Input Markets in Nigeria. IFDE, 2002.

[18] F. Romojaro, M. C. Martinez Madrid, and M. T. Pretzel, "Preharvest factors determining the quality and conservation postharvest agricultural products," 2007 (Spanish), http://www .horticom.com/pd/imagenes/65/906/65906.pdf.

[19] A. P. Rodaz and Y. P. Rizobacter, "Tratamiento para inducer color en citicos," 2005.

[20] J. G. Buwalda, "Nitrogen nutrition of garlic (Allium sativum L.) under irrigation. Components of yield and indices of crop 
nitrogen status," Scientia Horticulturae, vol. 29, no. 1-2, pp. 6976, 1986.

[21] A. A. Kakar, M. K. Abdullahzai, M. Salim, and S. A. Qaim Shah, "Effect of nitrogenous fertilizer on growth and yield of garlic. Agricultural Research Institute, Sariab, Quetta, Pakistan," Asian Journal of Plant Science, vol. 1, no. 5, pp. 544-545, 2002.

[22] M. A. Farooqui, I. S. Naruka, P. P. Singh, S. S. Rathore, and R. P. S. Shaktawat, "Effect of Nitrogen and sulphur levels on growth and yield of garlic (Allium sativum L.)," Asian Journal of Food and Agro-Industry, vol. 2, pp. 18-23, 2008.

[23] B. A. Babaji, Effect of plant spacing and nitrogen fertilization on growth and yield of garlic [M.S. thesis], ABU Zaria, Zaria, Nigeria, 1994.

[24] A. M. Bichi, Response of garlic (Allium sativum L.) to varying levels of phosphorus and nitrogen [B.Sc thesis], Department of Agronomy, ABU, Zaria, Nigeria, 1997.

[25] M. Djordge, B. Vukasin, S. Dubravka et al., "Effect of plant density on the characteristics of photosynthetic apparatus of the garlic (Allium sativum var. vulgare L.)," African Journal of Biotecnology, vol. 10, no. 71, pp. 15861-15868, 2011.

[26] J. M. Kowal and D. T. Knabe, An Agroclimatological Atlas of the Northern States of Nigeria, Ahmadu Bello University, Zaria, Nigeria, 1972.

[27] SAS, SAS Institute Inc., SAS Campus Drive, Cary, NC, USA, 2003.

[28] P. Kashiani and G. Saleh, "Estimation of genetic correlations on sweet corn inbred lines using SAS mixed model," American Journal of Agricultural \& Biological Science, vol. 5, no. 3, pp. 309314, 2010.

[29] T. Kassahun, Variability and association among bulb yield and yield related traits in garlic [M.S. thesis], Alemaya University, Dire Dawa, Ethiopia, 2006.

[30] K. Baghalian, M. R. Naghavi, S. A. Ziai, and H. N. Badi, "Postplanting evaluation of morphological characters and allicin content in Iranian garlic (Allium sativum L.) ecotypes," Scientia Horticulturae, vol. 107, no. 4, pp. 405-410, 2006.

[31] A. C. Hatfield-Nicholson Juniata, High Tunnel Garlic Variety Study-Plasticulture, Penn State Extension, College of Agricultural Sciences, 2010.

[32] R. E. McCollum, "Analysis of potato growth under different $\mathrm{P}$ regimes, time by $\mathrm{P}$-status interactions for growth and leaf efficiency," Agronomy Journal, vol. 70, pp. 58-66, 1978.

[33] M. Usman, Influence of different levels of nitrogen fertilizer on the growth and yield of garlic (Allium sativum L.) varieties under irrigation at Ajiwa, Katsina State, Nigeria [Bsc. thesis], Department of Crop Science, Faculty of Agriculture, ATBU, Bauchi, Nigeria, 2012.

[34] D. R. Panthee, P. P. Subedi, S. Bhattarai, and J. Dhakal, "Diversity analysis of garlic germplasm, available in Nepal based morphological characters," Genetic Resource Crop Evaluation Journal, vol. 53, no. 1, pp. 205-212, 2004.

[35] J. Bachmann and T. Hinman, "Garlic: Organic Production," National Center for Appropriate Technology, une publication d'ATTRA, États-Unis.[En ligne], 2008, https://attra.ncat.org/.

[36] A. G. Addissu, "Heritability and genetic advance in recombinant inbred lines for drought tolerance and other related traits in sorghum (sorghum bicolor)," Continental Journal of Agricultural Science, vol. 5, pp. 1-9, 2012. 


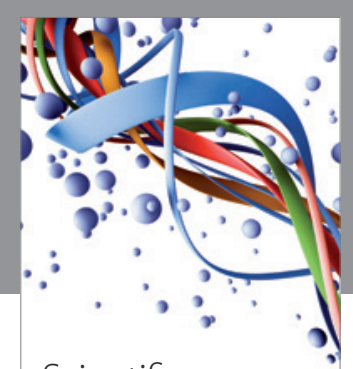

Scientifica
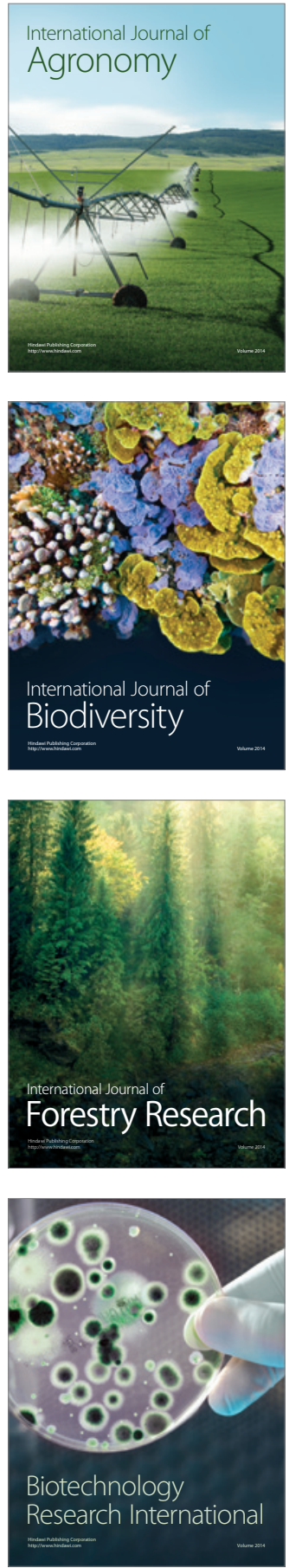
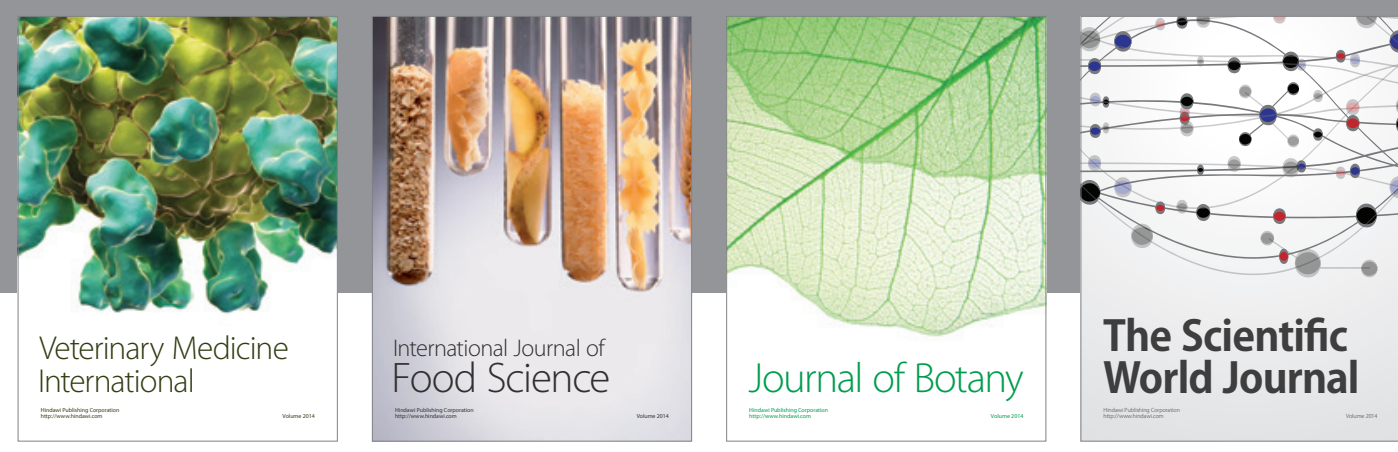

The Scientific

\section{World Journal}

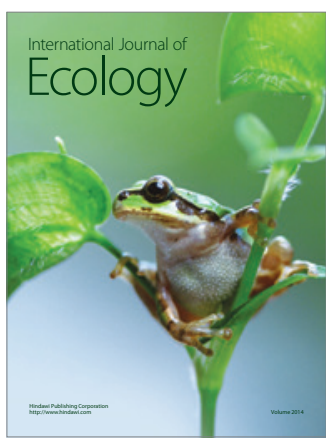

\section{Hindawi}

Submit your manuscripts at

http://www.hindawi.com
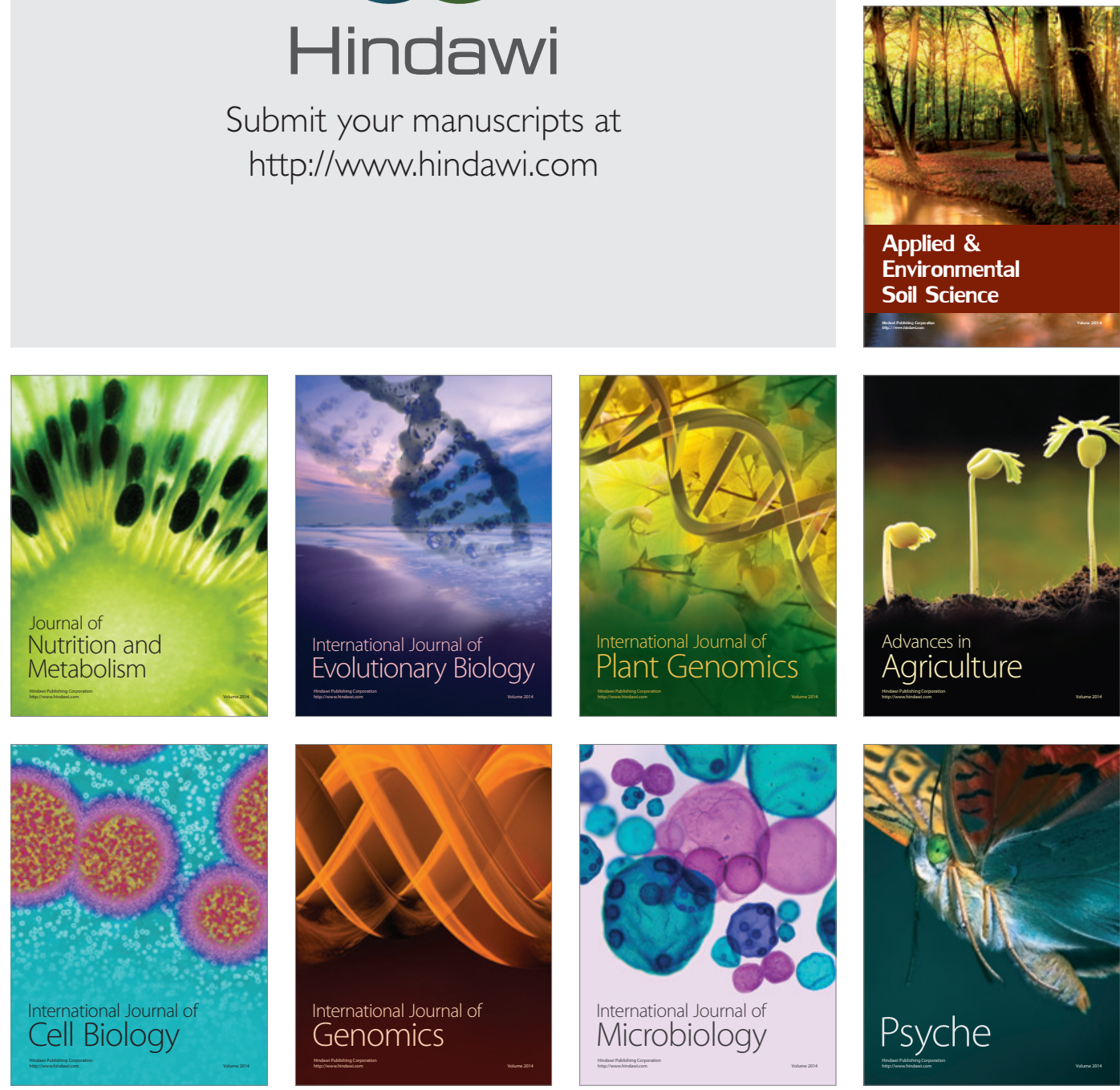
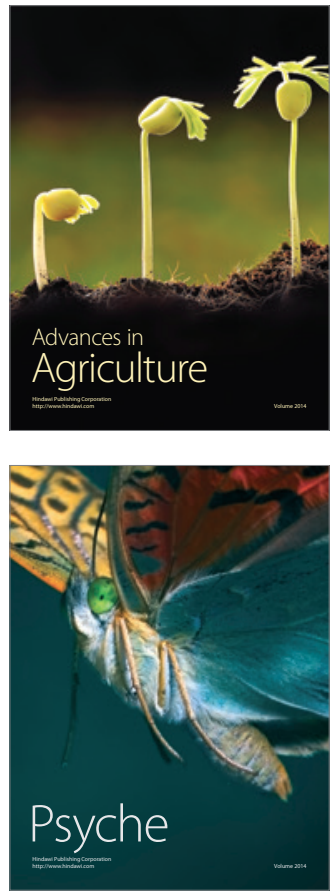